Peter Vaško ${ }^{1}$, Jakub Holly' ${ }^{2}$, Renata Stasiak-Betlejewska ${ }^{3}$

\title{
APPLYING THE PRINCIPLES OF CIRCULAR ECONOMY IN THE EUROPEAN UNION
}

\begin{abstract}
Consumer way of life, constantly acquiring material goods and their accumulation in the environment have created great imbalances, which has resulted in a present or an anticipated lack of natural resources, water, soil and air pollution or environmental pollution as such. Nowadays situation is alarming and this is the reason to change behaviour of current population and replace it with alternatives more favourable to the environment. For this reason, the European Union begins to apply the principles of reuse of scarce resources and streamlining production processes. One of these processes should be gradual application of circular economy, which is based on constant circulation of resources, resulting not only to reduce waste, but also to reduce production costs, increase employment opportunities etc. However, the transition to a circular economy requires participation on it by various organizations and individuals. For example, companies can make changes to a rebuilding of the complete supply chain for effective using of resources. Similarly, customers can adapt their buying behaviour and search only products produced by companies professed philosophy of circular economy. The aim of the work is based on the available empirical data and secondary research outline view of the circular economy as well as the application of the various principles of circular economy in practice.
\end{abstract}

Key words: Circular economy, marketing communication, environment, European Union

\section{Introduction}

Environment is natural base for economic activity of the people from whole world and from different society (MELEŠKIN M.T., ZAJCEV A.P., MARINOv CH. 1981). Therefore, suitable living conditions are directly

${ }^{1} \mathrm{MSc}$, PhD. student, Faculty of Mass Media Communication, University of Ss. Cyril and Methodius in Trnava, Slovakia, e-mail: petervasko.tt@gmail.com

${ }^{2}$ MSc, PhD. student, Faculty of Mass Media Communication, University of Ss. Cyril and Methodius in Trnava, Slovakia, e-mail: jakub.a.hollý@gmail.com

${ }^{3}$ Ing. PhD., supervisor, Institute of Production Engineering, Faculty of Management,

Czestochowa University of Technology, e-mail: renatastasiak@wp.pl 
dependent on the method of obtaining the raw materials. Human society obtains these valuable resources and subsequently transforms it to food, building of infrastructure, building the buildings, electrical appliance, but also to electric power production and much more. Also more and more we feel that the environment is not capable of producing raw materials at a rate at which comes to their Consumption. The biggest dilemma is the question of consumption the raw materials. Once it comes to the consumption of the product, or it is no longer to be used, we usually consider it as refuse. Thus it comes to the additional burden on the environment. Automatically, thus it comes to the additional burden on the environment.

Constantly increasing number of population, gradation of material consumption and increases of the wealth of the population in the current situation causes more than ever before the demand for scarce resources, which is ultimately reflected in the deterioration of the environment. In economic terms, this is reflected in the prices of metals, fossil fuels, as well in clean drinking water. It's very likely, this trend will continue. In this specific issue, there could be one possible solution: circular economy.

Needless to say that the environmental and economic activity of people should co-exist in a certain harmony and balance. Over the past period, we have witnessed the ever growing influence of those interests at the expense of environmental protection. In many cases, it results in environmental disaster, because the Earth is considered only as a raw material for economic growth. Such an understanding of the Earth is wrong, of course. The European Union is continually trying to support different forms of innovation, using specific programs and strategies, which is available by the politics of EU member states. One of the possibilities to achieve the positive effect on environment is using the modern techniques, such as circular economy. 


\section{Historical aspects of circular economy}

Circular economy represents modern and ambitious plan for creating an alternative for linear economy created in 19th century. Circular economy represents new idea that means significant progress in the way of creating, selling of products and also the consumption itself. It's very hard to track the birth of this concept. As it's known, first mentions started in the 60 s of the 20th century, when environmental protection became an actual topic. It's practical use to modern economies and industrial processes started in about 1970 first in academic field and later in first business organizations. Because of its great significance and practical use, shortly there was started a debate in professional circles. But the real development of circular economy based on theoretical assumptions comes after 1990. After this, individual countries presented their own concepts of circular economy. The forming process of circular economy continues and for example European Commission drafted laws connected to circular economy in 2014, with a view of more effective use of waste.

\section{Definition of circular economy}

The current process of production and consumption does not create only products and services, but also waste. In ideal world, this waste would be a reshaped and re-entered in the above process. The minimum raw loss is the main objective of circular economy. This principle of ecological economy should bring some specific methods that can transform until today useless part of the process, to reused resource. Scholarly interpretation of circular economy claims: Circular (closed) economy is the scientific concept of sustainable development model of economic management. It is basically type of a green economy. Circular economy is characterized by a closed loop (closed-loop) the flow of 
material and energy, taking into account the natural and human resources, science and technology (DARNADYOVÁ A. 2014).

Cyclic economy is moving away from the traditional linear economy, which plays a prim linear model: source - production - product, aimed at maximizing of the social wealth and profit, which excessively consumes natural resources and produces enormous quantities of waste. Therefore, the change of the system appears to be inevitable. Member States of the European Union are well aware of this fact. Transformation from a linear to a circular economy is the basis of the aims of the efficiency program of using resources, which was set out in the strategy 'Europe 2020 - A strategy for smart, sustainable and inclusive growth.

For circular economy it is crucial to keep the resources in use as long as it is possible, to achieve the maximal value from it, to renew and regenerate the products and materials in the end of each life circle. At the same time, circular economy is focused on separating the economic growth from using natural resources, by more effective way of using such resources. By the definition, circular economy is driving force of innovations in the area of materialism and reusing products, as well as new business models. In circular economy the more effective using of materials allows us to achieve bigger value while having lower costs. Also by penetrating to the new markets or development of the existing market. An important starting point for the implementation of this innovative process is creation of new innovative products, production processes and services. These innovative products are further proposed for the extension of their life cycle, so they can be modernized. It is also important for the process of circular economy, those products are located for reuse, or possibly recycle them into new products. Production processes are to be designed on the base/principle of re-use of raw materials and environmental protection. On the other hand, new relationships between companies and consumers can be created thanks of this process. For this purpose should serve marketing communications with a priority task to change the mindset of consumers from the current linear vision - production - consume - drop, would be changed to the 
circular. As well as to consumers, this marketing communications should affect on producers and by providing information about the advantages of such a model in terms of reducing costs and increasing sales. Thanks to the production of advanced/modern products that support sustainable development and corporate social responsibility, which will be in future increasingly required by consumers. The transformation to a circular economy requires many organizations and persons to participate. For example, companies can be useful by changing and rebuilding their supply chain for effective use of resources. Similarly, customers can adapt their shopping behaviour and seek only products manufactured by the philosophy of circular economy. A role of government organizations and politicians is to create legislative standards and benefits for the companies that decided to join this system.

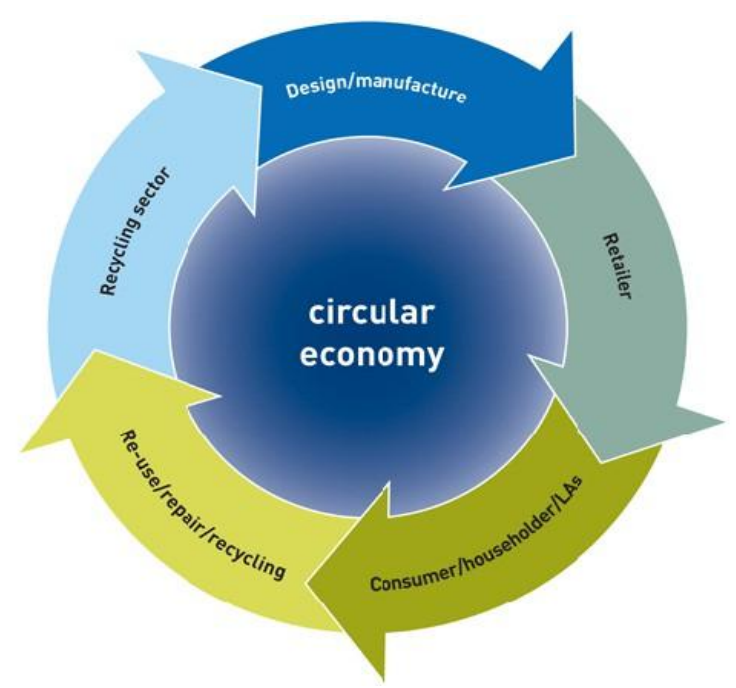

Fig. 1. Model of circular economy.

Source: WRAP (http:/http://www.wrap.org.uk/) 


\section{Principles of marketing communication in the conditions of circular economy}

For illustration, if marketing mix consists of the so-called. "4P", as well as cyclic economy is managed based on similar principles called the "3R". Those principles of traditional marketing mix like product, price, place and promotion are in circular economy replaced by- reduce, reuse, recycle:

- The principle of reduction (Reduce) - is the focus of a circular economy on technological progress and the introduction of innovations in production, distribution, sales and other areas in order to make more effective use of resources with the least possible use of raw materials and energy consumption. The supporting role of this principle is to achieve economic, social and ecological harmonization of production and the environment.

- The principle of reuse (Reuse) - means that manufacturers and design engineers should focus on the production of such products and packaging materials that are durable, resulting in an extension of their life cycle. Or those in which it is possible to be reused.

- The principle of recycling (Recycle) - When life of products is at the end, products and packaging materials can be reused such as available resources. Here emerges a certain risk connected with estimating profitability recovery.

Marketing communications also participates in the formation of different phases of circular economy:

- At the production stage, the standards of sustainable use of resources, voluntary systems led by industry and by retailers and industrial symbiosis to ensure markets for by-products

- At the stage of distribution "identification" products, which is one of the possible forms of communication to raise awareness of the resources contained in the products and about possibilities of 
repairment or recycling, as stated in the recommendations platform.

- At the stage of cohere-consumer consumption models based on borrowing, share, barter and leasing products and product delivery systems allowing a greater value of underused assets or resources (such as cars, tools, accommodation).

\section{Preparedness of the European Union on the circular economy}

A major supporter of resource efficiency and recycling are markets, because materials and energy have become major input costs for many companies. However, even if markets are now the driving force of change and growth, but in the same way they represent a set of barriers to the efficient and effective management of resources. The European Commission gradually began to develop concrete legislative proposals relating in particular to the Waste Framework Directive, the Landfill Directive and the Directive on packaging and packaging waste with efforts to transform the economy in the member states, so that it can efficiently use waste for further use on market. The transition to a circular economy is the basis of resource efficiency policies set out in the Europe 2020 strategy for smart, sustainable and inclusive growth (RAM. 2014).

This strategy is a ten-year strategy of the European Union, which was introduced in 2010 This strategy is focusing solely not only on tackling the economic crisis, but also to create the conditions for smart, sustainable and inclusive growth, which are also the three key priorities of the strategy. Thus, Europe 2020 is composed of three priorities, five goals (Increasing the employment rate to $75 \%$ from the current $69 \%$, investing 3\% GNP in research and development, climate change and energy - reducing greenhouse gas emissions by at least $20 \%$ compared from 1990 ... education - reduce early school leavers from the current $15 \%$ to $10 \%$, social inclusion - rip out at least 20 million EU citizens out of poverty and social exclusion) and to support these objectives the seven 
initiatives (Innovation in Union, Youth on the Move, a Digital agenda for Europe, resource efficient Europe, An industrial policy for the globalization era, agenda for new skills and jobs, European platform against poverty). We will work closer with approximately by two of the above mentioned initiatives, namely:

- Innovations in Union - to improve framework conditions and access to finance for research and innovation to ensure, that innovative ideas leading to the creation of products and services that provide growth and jobs.

- Resource-efficient Europe to help decouple economic growth from resource use, supporting the shift towards a low-carbon economy.

Turning waste into usable resources is also one of the fundamental objectives of the "Plan for Resource Efficiency". In this plan is emphasized particular need of paying much more attention to reuse and recycling. The aim of this plan is to create an economy based on total recycling, which includes the life cycle approach, better cooperation of all market players within value chain, better gathering processes, appropriate regulatory framework, incentives for waste prevention and recycling, as well as public investments in modern facilities for waste treatment and high quality recycling (Odpad ako hodnotný zdroj do budúcna).

To the introduction of the principle of circular economy, the European Union launched outwards from 2013, when actively started to have interest in waste management and in finding solution for this complex issue. Important milestones in the use of waste as a source of input to production (Euractiv.sk, 2013).

\section{Current conditions of solved problems in foreign countries}

In the current situation they are beginning to not only the governments and the public, but also individual companies aware of the 
need to establish sustainable economic development techniques. Many of them are switching to this model in order to ensure a competitive advantage, as customers increasingly demand products safe for health and for the environment. Among the first with interest in the transition from linear to circular forms of economy have become a Dutch companies. It is therefore not surprising that in this country is also the largest number of companies with the use of circular economy in practice.

\subsection{Netherlands}

The Dutch company Mud Jeans focuses on the use of circular economy in the garment industry and is one of the pioneers of using this model of the innovation process, i.e. new business models. It is a business model in the field of renewable energy, which is based on the principle of renting jeans produced from organic cotton. The jeans are made from $30 \%$ recycled content and $70 \%$ of organic cotton. This is innovative business plan of Dutch company, which activities leads to protect environment, but the main objective is to contribute to a new way of customer thinking, which of course is then reflected back into the environment. It is a principle of modern thinking about valuable raw materials in which the consumer buys jeans, but the material still remains in the lease of company. If the customer already does not wear this product, he sends it back to the company. The product is then transformed into the so-called unique. "Vintage denim", or may be a recycled and reused for a new product. This model is based on: The users can choose form of renting Mud Jeans for five euro's per month. After one year they have three options. Your jeans can be exchanged for a new pair and continue the lease for another year or four more months to pay a deposit and can be worn as long as they see fit. The last option is to end the relationship by returning jeans. Repairs are included in the lease. For those who have decided to leave the jeans, the company offers financial incentives for return items (ELLEN MACARTHUR FOUNDATION 2016). 
This type of business is a new innovative business model and can be classified as a departure from the traditional way of doing business. Specifically, the alternative of the traditional linear economies. This is the above-mentioned so-called. Circular economy. It means a fundamental shift in how the products are manufactured, sold and how comes to consumerism, all that, we can clearly see in the case of "Mud Jeans".

\subsection{Great Britain}

In terms of the UK, company Mazuma Mobile deals with the circular economy. The company provides online mobile services within the recycling and re-use. It provides its customers with new value mobile phones. If necessary, so mobile phones are going to renovate to an external partner and later goes to the sell-off in emerging markets or to retail outlets in the UK. The business activities Mazuma Mobile thus form so-called "Second-hand" mobiles.

\subsection{Sweden}

In public sector circular economy provides in addition to improving the environment also increasing the attractiveness of cities, with what goes, hand in hand, increasing number of job positions. But in today's world mainly based on fossil fuels is almost inconceivable to come to rising of national economy without the use of fossil fuels. One of those countries that have sought to do is Sweden. This country is working on a similar concept since 1990. Since that year, the country not only economic growth but also successfully reduced its emissions in the atmosphere. For 25 years they have managed to reduce emissions by $25 \%$, while the HPD increased by $58 \%$. They claim that one of the ways to achieve such positive results is the introduction of circular economy. As Stina Behrens from Transformation Design Group in Stockholm said: "Nine out of ten consumers do not know the concept of circular economy, but large companies certainly know him. There are quite a few companies 
that see new business opportunities within the circular economy. Swedish global players such as $\mathrm{H} \& \mathrm{M}$ and IKEA looking for a way to function in a loop. I believe that Sweden would be at the forefront of development of this new way of doing business." Swedish giants contribute to the overall economic growth of the country and in addition to the control and regulate of harmful impacts of their activities on the environment, human health and so on. Priorities of the Swedish Government are therefore efficient use of scarce resources, streamlining the production of products with extended life cycle and thus reduce overall waste. The transition to a circular economy in Sweden was introduced at Global Conference about Climate Change in Paris in 2015.

\subsection{Slovakia}

Slovakia is in its efforts to prepare and create conditions for the introduction of circular economy is much less ambitious. The level of recycling in Slovakia is still low and new recycling targets of the European Commission will be hardly achievable. Slovakia's position on this issue therefore remains restrained.

When comparing member states on preparedness for the introduction of circular economy, the basic problem is that many of them are at higher level than Slovakia. In particular the more advanced states that today can achieve currently valid targets. Slovakia is among those countries which do not even reach recycling targets, which are already in force and not much more ambitious targets to influence the economy so much that changes from linear to circular type. Considerable scepticism is heard not only from Slovakia but also from other member states that would promote Strategy 2020.

\section{Conclusion}

Is still needed to fine-tune and to overcome all the barriers that could hinder in introduction of such a model and in its smooth progress. It's 
necessary to secure the support of wider and better choices offered to consumers through leases, loans or shared services in terms of cost, security, information, terms and conditions, insurance and so on. However, the introduction of the principles of circular economy in practice is creating by more and more companies and was subject to examination by experts of the national economies in the European Union.

In conclusion, it could be appreciated that in the planning circular economy by EU, it should take into account the actual position of the countries, especially the current economic situation, which is different in each country. For some countries are targets realistic, for others are actual after a couple of years and for some are not real at all.

\section{Acknowledgements}

This work is related to the scientific research programme connected with scholarship programme of MSc Peter Vaško and MSc Jakub Hollý, PhD. students from University of Ss. Cyril and Methodius in Trnava, Faculty of Mass Media Communication in Slovakia, supported by programme CEEPUS III (CEEPUS Freemover No 338Z15/16) conducted since 02.05.2016 to 30.06.2016.

\section{Bibliography}

1. BENEŠOVÁ H. 2010. Environmentální technologie a ekoinovace. I. vydanie. Praha : CENIA, pp. 135. ISBN 978-80-85087-90-1.

2. DARNADYOVÁ A. 2014. Kruhová ekonomika (Circular Economy). [online] [In:] Odpadové hospodárstvo. Dostupné na internete: http://www.odpadyportal.sk/Dokument/102210/kruhova-ekonomika-circular-economy.aspx [cit. 2016-05-19]

3. ElLEN MACARTHUR FOUNDATION: The circular model - an overview. [online] [In:] <http://www.ellenmacarthurfoundation.org/circulareconomy/circular-economy/the-circular-model-an-overview> [cit. 2016-0519] 
4. Ellen Macarthur Foundation: Mud Jeans [online] [In:] <http://www.ellenmacarthurfoundation.org/case_studies/mud-jeans>. [cit. 2016-05-20]

5. KoŠturiaK J., CHAL‘ J. 2008. Inovace, vaše konkurenční výhoda!. Brno : Computer Press, pp. 216. ISBN 978-80-251-1929-7.

6. MELEŠKIN M.T., ZAJCEV A.P., MARINOV CH. 1981. Ekonomika a životné prostredie. Bratislava. ALFA, pp. 184. ISBN 978-80-95864-90-2.

7. Odpad ako hodnotný zdroj do budúcna. [Online]. Dostupné na < http://www.euractiv.sk/separovanie-a-samosprava/zoznam_liniek/odpadako-hodnotny-zdroj-do-buducna-000292>. [cit. 2016-05-20]

8. RAM. 2014. Nové pracovné miesta a udržatel’ný rast? Komisia má plán, ako na to! [Online]. Bratislava : Európske noviny, Júl 2014. [cit. 2016-04-06] Dostupné na internete: <http://www.europskenoviny.sk/2014/07/06/novepracovne-miesta-a-udrzatelny-rast-komisia-ma-plan-ako-na-to/>. [cit. 201605-20] 